\title{
Rapid development of megalopae of the fiddler crab Uca pugilator reared over sediment: implications for models of larval recruitment*
}

\author{
John H. Christy \\ Smithsonian Tropical Research Institute, Apartado 2072, Balboa, Republic of Panama \\ or \\ APO Miami, 340020011 , USA
}

\begin{abstract}
Fiddler crabs live as adults in estuaries but their planktonic larvae develop in the coastal ocean. Megalopae, the final larval stage, may return to adult habitats either slowly, via transport by residual currents near the bottom, or rapidly, by riding nocturnal flood tides. When reared in the laboratory over sediment from adult habitat, megalopae of the fiddler crab Uca pugilator molted to the crab stage in $7.5 \pm 1.64 \mathrm{~d}$ at 22 to $24^{\circ} \mathrm{C}$ and in $4.3 \pm 2.66 \mathrm{~d}$ at $28^{\circ} \mathrm{C}$. The rate of development over sediment is 2 to 3 times faster than rates observed when megalopae are reared in clean containers. On their second day of development, megalopae in a settlement tank remained on sediment exposed during artificial low tides and some molted to crabs a day later In clean containers, survival of megalopae and their competence to metamorphose declined with time while the occurrence of aberrant behavior increased. These results, together with what is known about the distribution and behavior of megalopae in coastal waters, are consistent with a mechanism of immigration into estuaries based on rapid transport of megalopae by tidal currents.
\end{abstract}

\section{INTRODUCTION}

Most fiddler crabs (genus Uca) occur as adults on intertidal substrates in estuaries and other protected coastal bodies of water (Crane 1975). Development is indirect (Hyman 1920) and includes 2 larval metamorphic molts: the first separating the 5 planktonic zoeal stages from the demersal megalopa, the second separating the megalopa from the benthic crab form.

The larvae of fiddler crabs do not develop near adult populations. Egg hatching and the release of larvae usually occurs near the time of nocturnal high tides on the days of the lunar month when nocturnal ebb tides are greatest in amplitude (reviewed by Forward 1987). As a result, stage I zoeae are transported rapidly away from adult habitat (Feest 1969, Salmon et al. 1986) and into the coastal ocean in the case of small estuaries (Christy \& Stancyk 1982, Brookins \& Epifanio 1985) or into the primary estuary in large estuarine systems (Sandifer 1973, Goy 1976, Dittel \& Epifanio 1982, Lam-

\footnotetext{
- Contribution No. 757 from the Belle W. Baruch Institute for Marine Biology and Coastal Research, University of South Carolina, USA
}

bert \& Epifanio 1982, Epifanio et al. 1988). In large estuaries, the subsequent zoeal stages are further displaced seaward during development with megalopae occurring commonly near or on the bottom in the vicinity of the bay mouth (Dittel \& Epifanio 1982) and on the inner continental shelf (Truesdale \& Andryszak 1983, Johnson 1985, Epifanio et al. 1988). This movement out of shallow estuarine waters probably is a true emigration (Strathmann 1982) away from areas of intense predation by fish (Morgan 1987). How do Uca megalopae immigrate into estuaries to colonize adult habitat?

Two mechanisms have been proposed to explain how $U_{C a}$ megalopae reach adult habitats. First, megalopae may remain near the bottom where residual flood-directed currents on the inner continental shelf (Bousfield 1955, Bumpus 1965, Scheltema 1975) will carry them into estuaries (Sandifer 1975, Goy 1976, Dittel \& Epifanio 1982, Lambert \& Epifanio 1982, Truesdale \& Andryszak 1983, Johnson 1985). Transport via this mechanism would be slow since bottom residual currents typically have velocities less than $0.1 \mathrm{~m} \mathrm{~s}^{-1}$. Second, although megalopae may remain low in the water column during the day, they may move up at 
night and ride nocturnal flood tides (Christy 1982 , Brookins \& Epifanio 1985, Epifanio et al. 1988). Immigration by riding nocturnal flood tides would be relatively fast as tidal current velocities in both coastal seas (Robinson 1983) and estuaries (Officer 1983) range typically from 0.5 to $1 \mathrm{~m} \mathrm{~s}^{-1}$. A recent conceptual model of recruitment by $U_{C a}$ megalopae (Epifanio et al. 1988) incorporates both modes of transport.

Here I report the results of a laboratory study of the effects of sediment from adult habitat on the duration of the intermolt of the megalopae of Uca pugilator. I compare these results with estimates of the length of the megalopal stage for this and other species in the genus UCa when reared in clean containers. I also provide notes on the behavior and survival of megalopae reared in a tank with sediment and in clean containers. The results provide indirect support for rapid transport of megalopae by tidal currents into estuaries.

\section{METHODS}

Zoeae. Ovigerous female Uca pugilator were collected at ca 2 wk intervals in 1978 and 1979 from sandy intertidal substrate in the North Inlet estuary, South Carolina, USA. Females were held in the dark in incubation tubes (Christy 1982) suspended in a tank filled with filtered $(1 \mu \mathrm{m})$ seawater at $34 \%$ salinity. Immersion heaters and a thermoregulator controlled $\left( \pm 0.5^{\circ} \mathrm{C}\right.$ ) the water temperature in the tank at 24 to $28^{\circ} \mathrm{C}$. Temperatures were chosen to match the seasonally variable sediment temperature at a depth of ca $15 \mathrm{~cm}$ where ovigerous females were collected. Approximately $1 \mathrm{~h}$ after hatching, usually between 20:00 and 23:00 h, zoeae from 9 to 12 clutches were washed from the incubation tubes, mixed in a glass bowl and transferred by pipet in groups of 10 to the compartments of clear plastic boxes each filled with $100 \mathrm{ml}$ of filtered $(0.45 \mu \mathrm{m})$ seawater at $34 \%$ salinity. Zoeae were transferred daily to fresh filtered seawater in clean boxes and were fed an excess of 1 to $3 \mathrm{~h}$ old nauplii of Artemia salina. Three rearing experiments were done in plastic boxes, one each at 22,24 and $28^{\circ} \mathrm{C}$ under a 14.10 ìght: dark (LD) cycle in an environmental chamber. In a fourth experiment to obtain a large number of megalopae, several thousand zoeae were mass-reared at $28^{\circ} \mathrm{C}$ and $34 \%$ under a 14:10 LD schedule in a 10 l glass tank in the environmental chamber. Artemia nauplii were added daily and the water was changed by syphoning every third day. Each experiment was done at a time of the breeding season when the rearing temperature corresponded closely to the temperature of the water in the North Inlet estuary (Christy 1982).

Megalopae. Megalopae that developed from zoeae in clean plastic boxes were reared subsequently to the first crab stage in boxes that had a thin layer of muddysand on the bottom of each compartment. Megalopae were reared at the same temperature $\left(22,24\right.$ or $28^{\circ} \mathrm{C}$ ) and salinity they experienced as zoeae. Two megalopae were reared per compartment. Megalopae were transferred daily to a new compartment with freshly collected sediment, filtered seawater and Artemia nauplii. Sediment was collected daily during low tide by scraping with a spatula the top 2 to $3 \mathrm{~mm}$ of sand adjacent to the burrows of adult $U_{c a}$ pugilator. An effort was made to keep the upper surface of the sediment uppermost in the rearing compartments, but the mechanics of transfer caused some mixing.

Megalopae appeared in the mass rearing at $28^{\circ} \mathrm{C}$ and $34 \%$ over a period of $12 \mathrm{~d}$. Those obtained on Days 4 and 6 to 10 were reared at the same temperature and salinity without sediment in the compartments of clean plastic boxes. They were fed and transferred daily as for the other cultures.

To observe the behavior of megalopae during artificial tides, 53 megalopae obtained from the mass culture on Day 5 were placed in a plastic settlement tank (ca 101) fitted with an inclined plastic tray covered with a 2 to $3 \mathrm{~mm}$ thick layer of sediment from adult habitat. The walls and bottom of the tank were perforated with holes screened with 153 um mesh nylon netting. The settlement tank was suspended in a larger tank filled with filtered seawater at $28^{\circ} \mathrm{C}$ and $34 \%$. The level of water in the settling tank was gradually ( $45 \mathrm{~min}$ ) lowered in the mid-morning until all the sediment was exposed. The sediment was left exposed for about $2.5 \mathrm{~h}$ and then the water was raised gradually to cover the sediment. When the tank was drained, about $3 \mathrm{~cm}$ of water remained in a trough below the lower edge of the tray with sediment. I watched the megalopae in the tank during this simulated tidal cycle, and counted and removed first stage crabs during the artificial low tide period. The water level was cycled daily until no more megalopae were seen in the tank. Megalopae were fed Artemia daily but they were not handled nor was the sediment changed.

\section{RESULTS}

\section{Development of zoeae}

Temperature had a significant effect on the development rates of zoeae (Table $1 ; F_{s(3,567)}=99.919$, $\mathrm{p} \ll 0.001)$. Zoeae reared in plastic boxes had nearly identical and significantly slower development rates at 22 and $24^{\circ} \mathrm{C}$ than at $28^{\circ} \mathrm{C}\left(\mathrm{F}_{\mathrm{s}(1,567)}=284.559, \mathrm{p} \ll 0.001\right)$. Zoeae that were mass-reared at $28^{\circ} \mathrm{C}$ developed significantly more slowly than did zoeae that were reared in boxes at the same temperature $\left(\mathrm{F}_{\mathrm{s} \mid 1,567)}=116.118\right.$, 
Table 1. Uca pugilator. Duration of development from hatching to megalopa when reared at 3 temperatures

\begin{tabular}{|lccccc|}
\hline \multicolumn{2}{c}{$\begin{array}{c}\text { Rearing conditions } \\
\text { Container }\end{array}$} & N & $\begin{array}{c}\% \\
\text { Survival }\end{array}$ & & Ruration (d) \\
Plastic boxes & 22 & 230 & 76 & $16-27$ & $19.4 \pm 2.14$ \\
& 24 & 120 & 62 & $15-31$ & $19.6 \pm 3.02$ \\
Glass tank & 28 & 160 & 59 & $12-20$ & $14.7 \pm 1.83$ \\
& 28 & $2000-5000$ & ca 10 & $13-24$ & $17.7 \pm 2.33$ \\
\hline
\end{tabular}

$\mathrm{p} \ll 0.001 \mathrm{j}$ and significantly faster than zoeae reared in boxes at 22 and $24^{\circ} \mathrm{C}\left(\mathrm{F}_{\mathrm{s}(1,567)}=65.048, \mathrm{p} \ll 0.001\right)$. Survival of zoeae in the mass rearing probably was less than $10 \%$, perhaps because of inadequate food or effects related to crowding, while survival rates of zoeae in the box cultures were higher (Table 1).

\section{Development of megalopae: effect of temperature}

The durations of the intermolt of megalopae reared at different temperatures in boxes with sediment differed significantly (Table $2 ; F_{\mathrm{s}(2,201)}=164.956$, $\mathrm{p} \ll 0.001$ ). Development rates at 22 and $24^{\circ} \mathrm{C}$ were similar and significantly slower than the rate at $28^{\circ} \mathrm{C}$ $\left(F_{s(1,201)}=309.782, p \ll 0.001\right)$. The intermolt duration of megalopae reared at $28^{\circ} \mathrm{C}$ with sediment in the settlement tank was longer than the intermolt duration of megalopae reared in boxes with sediment at the same temperature $\left(F_{\mathrm{s}(1.73)}=7.728, \mathrm{p}<0.007\right)$. At the 2 cooler temperatures, typical of the early breeding season in the North Inlet estuary and coastal ocean, megalopae molted to the crab stage in $7.5 \pm 1.64 \mathrm{~d}$. At $28^{\circ} \mathrm{C}$, the temperature of the water in the middle to late breeding season, larvae spent only $4.3 \pm 2.66 \mathrm{~d}$ as megalopae.

The distributions of the intermolt durations in these 4 experiments with sediment did not differ significantly from expected normal distributions (Fig. 1; Lilliefors

Table 2. Uca spp. Intermolt durations of megalopae of fiddler crabs reared with or without sediment from adult habitat

\begin{tabular}{|c|c|c|c|c|c|c|c|c|c|c|c|}
\hline \multirow[t]{3}{*}{ Species } & \multicolumn{4}{|c|}{ Rearing conditions } & \multicolumn{6}{|c|}{ Duration (d) of megalopal intermolt } & \multirow[t]{3}{*}{ Source } \\
\hline & Temp. & Sal. & Light & Food & & Survival & & Meán & Median & Skew ${ }^{b}$ & \\
\hline & $\left({ }^{\circ} \mathrm{C}\right)$ & & cycle & & $\mathrm{N}$ & $\%$ & Range & $\pm \mathrm{SD}$ & & & \\
\hline \multicolumn{12}{|l|}{ With sediment } \\
\hline U. pugilator & 22 & 34 & $14: 10$ & A & 121 & 90 & $6-11$ & $7.5 \pm 0.88$ & - & No & This study \\
\hline U. pugilator & 24 & 34 & $14: 10$ & A & 67 & 78 & $4-12$ & $7.3=1.62$ & - & No & (Plastuc boxes) \\
\hline U. pugilator & 28 & 34 & $14: 10$ & A & 44 & 98 & $3-6$ & $4.0 \pm 0.63$ & - & No & (Plastic boxes) \\
\hline U. pugilator & 28 & 34 & $14: 10$ & A & 53 & 60 & $2-8$ & $4.7 \pm 1.27$ & - & No & (Settlement tank) \\
\hline \multicolumn{12}{|l|}{ Without sediment } \\
\hline U. puglator & 20 & 30 & $14: 10$ & $\mathrm{AAb}$ & - & - & - & - & 11 & $?$ & Vernberg \& Vernberg $(1975)^{\circ}$ \\
\hline U. pugilator & 25 & 30 & $14: 10$ & $A A B$ & - & - & -- & - & 11 & ? & Vernberg \& Vernberg (1975) \\
\hline$U$. pugilator & 27 & 35 & $?$ & A & - & - & $14-21$ & - & - & ? & Herrnkind $(1968)^{d}$ \\
\hline U. pugilator & 28 & 34 & $14: 10$ & A & 120 & 84 & $5-55$ & $12.9 \pm 7.71$ & - & Yes & This study \\
\hline U. puglator & 29 & 33 & $?$ & $A$ & 34 & 91. & $5-15$ & $6.5 \pm 2.59$ & - & Yes & Christiansen \& Yang (1976) \\
\hline U. pugilator & 29 & 33 & $?$ & A & 36 & 94 & $4-14$ & $6.4 \pm 2.26$ & - & Yes & Christiansen \& Yang (1976) \\
\hline U. pugilator & 29 & 33 & $?$ & AS & 35 & 97 & $5-15$ & $5.7 \pm 1.89$ & - & Yes & Chnstiansen \& Yang (1976) \\
\hline U. pugilator & 29 & 33 & $?$ & AS & 35 & 97 & $4-15$ & $6.1 \pm 2.29$ & - & Yes & Christiansen \& Yang (1976) \\
\hline$U$. pugilator & 29 & 33 & ? & $\mathrm{BE}$ & 18 & 17 & $8-11$ & $9.3 \pm 1.54$ & - & No & Christuansen \& Yang (1976) \\
\hline U. pugnax & 20 & 30 & $14: 10$ & $A A b$ & - & - & - & - & 17 & $?$ & Vernberg \& Vernberg $(1975)^{\circ}$ \\
\hline U. pugnax & 25 & 25 & $12: 12$ & A & 14 & - & $7-18$ & $12.5 \pm 3.0$ & - & Yes & Wheeler (1978) \\
\hline U. pugnax & 25 & 20 & $14: 10$ & $A$ & 66 & 41 & - & $17.7 \pm 4.0$ & - & Yes & O'Conner \& Epifanio (1985) \\
\hline U. pugnax & 25 & 30 & $14: 10$ & A & 39 & 16 & - & $20.6 \pm 57$ & - & Yes & \\
\hline U. pugnax & 25 & 20,30 & $14: 10$ & A & $50-80$ & 10 & $25-40$ & - & - & Yes & Epifanio et al. (1988) \\
\hline$U . \min a x$ & 25 & 30 & $14: 10$ & $\mathrm{AAb}$ & - & - & - & - & 14 & ? & Vernberg \& Vernberg $(1975)^{c}$ \\
\hline U. $\min a x$ & 25,10 & 20,30 & $14: 10$ & A & $29-73$ & $4-26$ & $25-40$ & - & - & Yes & Epifanio et al. (1988) \\
\hline U. rapax & 25 & 30 & $14: 10$ & A A b & - & - & - & - & 11 & $?$ & Vernberg \& Vernberg $(1975)^{c}$ \\
\hline U. lactea & $27-30$ & $26-33$ & ? & $\mathrm{M}$ & - & - & - & - & 17 & ? & Feest (1969) \\
\hline U. triangularis & $27-30$ & $26-33$ & ? & $M$ & - & - & - & - & 16 & ? & Feest (1969) \\
\hline U. subcylindrica & $25-30$ & 15,30 & $14: 10$ & $A B Z$ & - & - & $3.5-8$ & 5.5 & - & $?$ & Rabalais \& Cameron (1983) \\
\hline \multicolumn{12}{|c|}{$\begin{array}{l}\text { A: Artemia salina; Ab: Arbacia (urchin) eggs; B: Brachionus plicatilis (rotifer); E: Euplotes (ciliate); S: minced shrimp; M: mixed plankton diet; } \\
\text { Z: zoeae of other Uca }\end{array}$} \\
\hline \multicolumn{12}{|c|}{$\begin{array}{l}{ }^{b} \text { Positive skew judged by statistical tests (this study), location of the mean near the lower limit of the range or by authors' statements that some } \\
\text { megalopae delayed metamorphosis considerably }\end{array}$} \\
\hline \multicolumn{12}{|c|}{ Value for median estimated as the midpoint of graphed range } \\
\hline "A thin layer of & nd of un & stated or & gin was & added to & he rearn & ng tar & & & & & \\
\hline
\end{tabular}


tests, $p \gg 0.20$ for all experiments). No evidence of cannibalism was observed and survival was good, ranging from a low of $60 \%$ in the settlement tank to $98 \%$ in the boxes at $28^{\circ} \mathrm{C}$. The lower apparent survival and slightly longer intermoult recorded for megalopae in the settlement tank may have been due, in part, to experimental error since it was very difficult to locate the cryptic first crabs on and in the sediment.

\section{Development of megalopae: effects of sediment}

The intermolt duration of megalopae reared at $28^{\circ} \mathrm{C}$ in boxes without sediment averaged $12.9 \pm 7.72 \mathrm{~d}$,

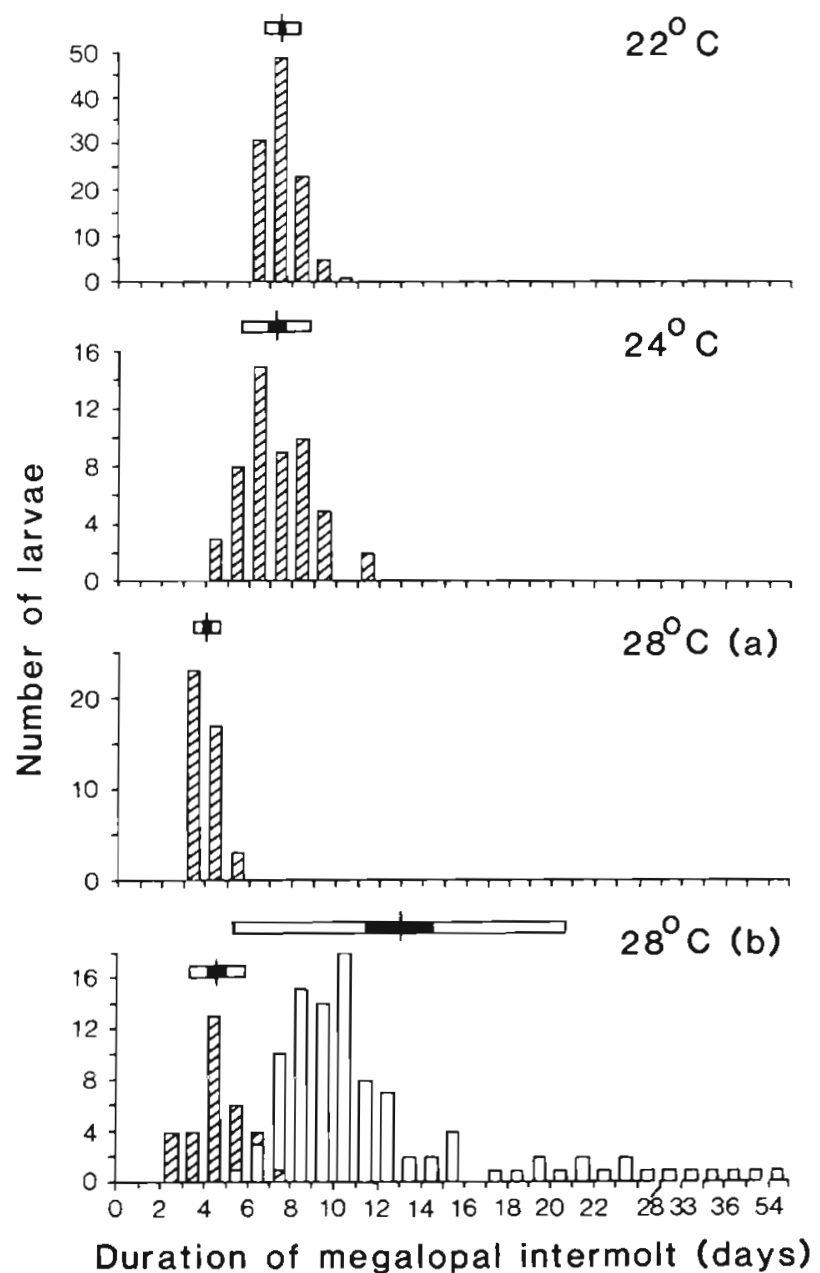

Fig. 1. Uca pugilator. Effect of temperature and sediment from adult habitat on the duration of the intermolt of megalopae. (a) Megalopae from different zoeal cultures were reared in boxes over sediment (hatched bars) at 22,24 and $28^{\circ} \mathrm{C}$. (b) Those from a single culture at $28^{\circ} \mathrm{C}$ were reared either in a tank with sediment or in boxes without sediment (open bars). Horizontal bars show one standard deviation and 2 standard errors above and below the mean intermolt duration (Table2) for each culture significantly longer (Mann-Whitney U-test, $U_{5}=3.210$, $\mathrm{p} \ll 0.001$ ) than the $4.7 \pm 1.27 \mathrm{~d}$ intermolt period of megalopae reared over sediment in the settlement tank and under identical conditions as zoeae (Fig. 1). Intermolt durations of megalopae reared without sediment were not normally distributed (Fig. 1; Lilliefors test, $\left.D_{\max }=0.2486, p \ll 0.001\right)$ showing significant skew $\left(g_{1}=2.81 \pm 0.240, t_{s}=11.70, p \ll 0.001\right)$ toward long development periods of up to $55 \mathrm{~d}$.

In this culture lacking sediment, megalopae exhibited what appeared to be pathological behavior later in development and they had reduced survival the longer they delayed molting. Early in development, megalopae either swam actively, usually with their dorsal surface uppermost, along approximately straight paths between the bottom and walls of the compartments of the boxes, or they rested or crawled on the bottom (sometimes feeding) with their abdomen curved slightly under their carapace, again in an upright orientation. On Day 20 of development I first noticed some megalopae resting upside down or swimming upside down in tight circles on the bottom or in vertical loops or spirals. I could touch with a probe and even turn over megalopae resting on the bottom before they swam away. I seldom saw megalopae feed later in development. The survival rate of megalopae declined, but not significantly so $(G=2.730,0.10>p>0.05)$, from $87 \%(86 / 99)$ up to Day 20 to $71 \%(15 / 21)$ from Day 21 to the end of the experiment.

\section{Behavior of megalopae in the settlement tank}

Observations of megalopae in the settlement tank suggest that they are capable of remaining on exposed intertidal substrate very early in development. The water in the tank was first lowered the day after 53 megalopae were added to the tank. Just before I drained the tank I saw some megalopae swimming actively and others crawling on the surface of the sediment. As the water level dropped and exposed the sediment some megalopae remained on the surface of the muddy-sand. About $1 \mathrm{~h}$ later I scanned the surface with a hand lens and saw 2 megalopae resting exposed. Faint traces on the sediment revealed the presence of 6 others buried just beneath the surface. About an hour later the water in the tank was raised slowly (45 min to cover the sediment). Some megalopae immediately swam into the water as it covered them, but I was not able to account for all those I had seen on the sediment during the low tide period suggesting that some megalopae remained buried. I made similar observations for the next $2 \mathrm{~d}$ by which time I first found crabs on the sediment. 


\section{DISCUSSION}

\section{Duration and distribution of the intermolt of fiddler crab megalopae}

When reared with sediment from adult habitat, megalopae of the fiddler crab Uca pugilator molt to the first crab about 2 to 3 times faster than when they are reared in clean containers (or with a thin layer of sand of unknown origin; Table 2). The distributions of development times tend to be normally distributed when megalopae are reared over sediment and positively skewed in this and other species of Uca when clean containers are used for rearing (Table 2).

Relatively rapid development of fiddler crab megalopae has been reported in 2 other studies. Christiansen \& Yang (1976) reared Uca pugilator megalopae, obtained from a single clutch of one female, at 28 to $30^{\circ} \mathrm{C}$ without sediment (Table 2). The means of the estimates of the megalopal intermolt from these experiments are close to the lower limits of their ranges, and the standard deviations are relatively large, indicating positive skew in the distributions of intermolt durations as expected when sediment is not provided. At a slighly cooler temperature, development rates of megalopae reared over sediment in the present study were about 2 to $2.5 \mathrm{~d}$ (30 to $40 \%$ ) faster. Uca subcylindrica megalopae, reared without sediment, also develop rapidly (Rabalais \& Cameron 1983). However, the rapid development of $U$. subcylindrica is part of a syndrome of adaptations for breeding in temporary ponds in an arid environment (Rabalais \& Cameron 1983, Thurman 1984 ) and is not directly comparable to other species in the genus.

\section{Implications for models of recruitment}

The present study has demonstrated clear differences between the durations and the distributions of the intermolt of $U_{C a}$ pugilator megalopae reared with sediment and in clean containers. What are the implications of these differences for understanding how megalopae immigrate to estuaries from the coastal ocean where zoeae develop?

Transport of megalopae into and up estuaries by residual flood-directed currents (Sandifer 1975, Dittel \& Epifanio 1982, Johnson 1985, Epifanio et al. 1988) would proceed at rates generally $<0.1 \mathrm{~m} \mathrm{~s}^{-1}$ (Bumpus 1965, Scheltema 1975, Robinson 1983) and would take one to several weeks depending on the distance of the necessary migration and current strength. There is evidence (Sandifer 1973, 1975, Goy 1976) that the later zoeal stages of fiddler crabs concentrate near the bottom (but see Dittel \& Epifanio 1982), and perhaps begin immigra- tion before the megalopal stage is reached. However, Johnson (1985) found Uca megalopae at highest densities on the inner continental shelf $8 \mathrm{~km}$ outside the mouth of the Chesapeake Bay and Truesdale \& Andryszak (1983) caught the later zoeal stages and megalopae in abundance in nearshore coastal waters in Louisiana. Hence, megalopae must regularly immigrate to estuaries over distances of tens of kilometers. Slow transport by residual currents would seem to be an effective mechanism for immigration if the duration of the megalopal intermolt typically is as long as that observed in experiments in which megalopae are reared in clean containers. Thus, this mechanism would seem to apply to what megalopae can do when forced to delay settlement and metamorphosis for lack of suitable sediment on which to settle. In the present study, megalopae reared without sediment exhibited aberrant behavior and increased mortality as the duration of the megalopal intermoult increased. In many other benthic invertebrates with meroplanktonic larvae, substrate selectivity and survival after settling decline the longer larvae delay metamorphosis (Chia \& Rice 1978). It is likely that the cumulative probability of death due to predation increases with the length of larval life as well. Hence, slow transport of megalopae into and up estuaries along the bottom probably would be effective only for a proportionately small number of larvae that survive longest out of the total larval population.

An alternative and more rapid mechanism for immigration to estuaries is for megalopae to swim with the current during flood tides and to rest on the bottom at other times (Christy 1982, Epifanio et al. 1988). At North Inlet at a station in the upper estuary (Christy 1982) and at 3 stations along a transect from near the mouth to the upper estuary (J. Christy \& S. Morgan unpubl.) Uca megalopae were abundant in the water column during nocturnal flood tides and nearly absent during nocturnal ebb and diurnal flood tides. Appropriate sampling schemes have revealed similar patterns in other estuaries (Brookins \& Epifanio 1985, Epifanio et al. 1988). It is not yet known whether megalopae in coastal waters also swim up in the water column only during nocturnal flood tides. However, nearly all of the Uca megalopae Johnson (1985) caught in daytime samples in the Chesapeake Bay and on the inner continental shelf were on the bottom, as expected if megalopae are epibenthic during daytime hours. Thus, megalopae may immigrate to adult habitats in a saltatorial fashion by riding nocturnal flood tides. Using estimates of 0.5 to $1.0 \mathrm{~m} \mathrm{~s}^{-1}$ for flood velocities in the Delaware Bay (Pape \& Garvine 1982), Epifanio et al. (1988) estimate that $U_{C a}$ megalopae could be carried 11 to $22 \mathrm{~km}$ upstream per flood tide and across the entire range of adult habitats in this very large estuarine system in 7 to $14 \mathrm{~d}$. Maximum flood velocities in the 
North Inlet estuary range from about $2 \mathrm{~m} \mathrm{~s}^{-1}$ in the mouth of the inlet to about $0.5 \mathrm{~m} \mathrm{~s}^{-1}$ in the upper estuary (Kjerfve et al. 1982). In this system Uca megalopae could enter the estuary and be carried to its upper reaches $(6$ to $8 \mathrm{~km}$ ) on a single nocturnal flood tide. Without data on the movements of identifiable cohorts of megalopae it is difficult to judge the accuracy of these estimates. On the one hand, they may overestimate rates of up-estuary transport because they do not account for variation in flood current velocities and they assume that megalopae are in the water column during the entire flood tide. On the other hand, these rough estimates may be slightly conservative if megalopae swim with flood currents and thereby increase their ground speed. Swimming speeds of $U C a$ megalopae have reported to range from 15 to $20 \mathrm{~cm} \mathrm{~s}^{-1}$ (H. G. Nosler cited in Feest 1969), somewhat greater than speeds of 3 to $12 \mathrm{~cm} \mathrm{~s}^{-1}$ measured for other brachyuran megalopae (Sulkin \& Van Heukelem 1982, Chia et al. 1984).

Rapid migration of Uca megalopae to adult habitats via transport by nocturnal flood tides is supported by studies of the distribution and abundance of megalopae in the water column over space and time and it incorporates both the demersal habit of megalopae and, as revealed by this study, their ability to settle and metamorphose very early in development. It is likely that megalopae become competent to settle soon after metamorphosis from the final zoeal stage because they immigrate rapidly into estuaries and therefore regularly encounter sediment suitable for settlement early in life. Early competence would not be expected if immigration was affected solely through passive transport by weak residual currents and megalopae typically encountered adult habitats only later in the intermolt. I suggest that most megalopae that colonize adult habitats successfully do so quickly by swimming with nocturnal flood tides rather than by means of transport phenomena that require delays to metamorphosis that may be accompanied by loss of competency and increased mortality.

Acknowledgements. I thank $\mathrm{H}$. Lessios, S. Morgan and R. Robertson for their comments on a draft of this paper, $\mathrm{J}$. Bordua for preparing the figure and the staff of the Baruch Field Laboratory for their capable assistance. This research was supported by Grant OCE 77-20960 from the National Science Foundation and by funds from the Smithsonian Tropical Research Institute.

\section{LJTERATURE CITED}

Bousfield, E. L. (1955). Ecological control of the occurrence of barnacles in the Miramichi Estuary. Bull natn. Mus. Can. 137. Biol. Ser. No. 46: 1-69
Brookins, K. G., Epifanio, C. E. (1985). Abundance of brachyurcin larvae in a small coastal inlet over six consecutive tidal cycles. Estuaries 8: 60-67

Bumpus, D. F. (1965). Residual drift along the bottom on the continental shelf in the Middle Atlantic Bight area. Limnol. Oceanogr. Suppl. 10: R50-R53

Chia, F.-S., Buckland-Nicks, J., Young, C. M. (1984). Locomotion of marine invertebrate larvae: a review. Can. J. Zool. 62. $1205-1222$

Chia, F.-S., Rice, M. E. (1978). Settlement and metamorphosis of marine invertebrate larvae. Elsevier, New York

Christiansen, M. E., Yang, W. T (1976). Feeding experiments on the larvae of the fiddler crab Uca pugilator (Brachyura, Ocypodidae), reared in the laboratory. Aquaculture 8: 91-98

Christy, J. H. (1982). Adaptive significance of semilunar cycles of larval release in fiddler crabs (genus $U_{c a}$ ): test of an hypothesis. Biol. Bull. mar biol. Lab., Woods Hole 163: $251-263$

Christy, J. H., Stancyk, S. E. (1982). Tiraing of larval production and flux of invertebrate larvae in a well-mixed estuary. In: Kennedy, V. (ed.) Estuarine comparisons. Academic Press, New York, p. 489-503

Crane, J. (1975). Fiddler crabs of the world. Princeton University Press, Princeton

Dittel, A. I., Epifanio, C. E. (1982). Seasonal abundance and vertical distribution of crab larvae in Delaware Bay, USA. Estuar. cstl Shelf Sci. 18: $1-12$

Epifanio, C. E., Little, K. T., Rowe, P. M. (1988). Dispersal and recruitment of fiddler crab larvae in the Delaware River estuary. Mar. Ecol. Prog. Ser. 43: 181-188

Feest, J. (1969). Morphophysiological studies on the ontogeny and sexual biology of Uca annulipes and Uca triangularis as compared to Ilyoplax gangetica. Forma Functio 1: $159-225$

Forward, R. B. Jr. (1987). Larval release rhythms: an overview. Buil. mar. Sci. 41: 165-176

Goy, J. W (1976). Seasonal distribution and the retention of some decapod crustacean larvae within the Chesapeake Bay, Virginia. M. S thesis, Old Dominion University, Newark, Delaware

Herrnkind, W. F. (1968). The breeding of Uca pugilator (Bosc) and mass rearing of the larvae with comments on the behavior of the larval and early crab stages (Brachyura, Ocypodidae). Crustaceane Suppl. II: 214-224

Hyman, O. W. (1920). On the development of Gelasimus after hatching. J Morph. 33: 485-525

Johnson, D. F. (1985). The distribution of brachyuran crustacean megalopae in the waters of the York River, lower Chesapeake Bay and adjacent shelf: implications for recruitment. Estuar cstl Shelf Sci. 20: 693-705

Kjerfve, B., Proehl, J. A., Schwing, F. B Seim, H E Marozas, M. (1982). Temporal and spatial considerations in measuring estuarine water fluxes. In: Kennedy, V S. (ed.) Estuarine compansons. Academic Press, New York, p. 37-51

Lambert. R., Epifanio, C. E. (1982). A comparison of dispersal strategies in two genera of brachyuran crab in a secondary estuary. Estuaries 5: 182-188

Morgan, S. (1987). Morphological and behavioral antipredatory adaptations of decapod zoeae. Oecologia (Berl.) 73: $393-400$

O'Connor, N. J., Epifanio, C. E. (1985). The effect of salinity on the dispersal and recruitment of fiddler crab larvae. J. crust. Biol. 5: 137-145

Officer, C. B. (1983). Physics of estuanne circulation. In: Ketchum, B. H. (ed.) Estuaries and enclosed seas. Elsevier. Amsterdam, p. 15-41 
Pape, E. H. III, Garvine, R. W. (1982). The subtidal circulation in Delaware Bay and adjacent shelf waters. J geophys. Res. 87: 7955-7970

Rabalais, N. N., Cameron, J. N. (1983). Abbreviated development of Uca subcylindrica (Stimpson, 1859) (Crustacea, Decapoda, Ocypodidae) reared in the laboratory. J. crust Biol. 3: 519-541

Robinson, I. S. (1983). Tidally induced residual flows. In: Johns, B. (ed.) Physical oceanography of coastal and shelf seas. Elsevier, Amsterdam, p. 321-356

Salmon, M., Seiple, W H., Morgan, S. G. (1986). Hatching rhythms of fiddler crabs and associated species at Beaufort, North Carolina. J. crust. Biol. 6: 24-36

Sandifer, P. A. (1973). Distribution and abundance of decapod crustacean larvae in the York River estuary and adjacent lower Chesapeake Bay, Virginia, 1968-1969. Chesapeake Sci. 14: 235-257

Sandifer, P. A. (1975). The role of pelagic larvae in recruitment to populations of adult decapod crustaceans in the York River estuary and adjacent lower Chesapeake Bay, Virginia. Estuar. cstl mar. Sci. 3: 269-279

Scheltema. R. S. (1975). Relationship of larval dispersal, geneflow and natural selection to geographic variation of

This article was presented by Professor R. B. Forward, Beaufort, N. Carolina, USA benthic invertebrates in estuaries and along coastal regions. In: Cronin, L. E. (ed.) Estuarine research, Vol 1 Academic Press, New York, p. 373-391

Sulkin, S. D., V'an Heukelem, W (1982). Larval recruitment in the crab Callinectes sapidus Rathbun: an amendment to the concept of larval retention in estuaries. In: Kennedy, V.S. (ed.) Estuarine comparısons. Academic Press, New York, p. $459-475$

Strathmann, R. R. (1982). Selection for retention or export of larvae in estuaries. In: Kennedy, V S. (ed.) Estuarine comparisons. Academic Press, New York, p. 521-536

Thurman, C. L. II (1984). Ecological notes on the fiddler crabs of south Texas, with special reference to Uca subcylindrica. J. crust. Biol. 4: 665-681

Truesdale, F. M., Andryszak, B. L. (1983). Occurrence and distribution of reptant decapod crustacean larvae in neritic Louisiana waters: July 1976. Contr. mar Sci. 26: 37-53

Vernberg, F. J., Vernberg, W B. (1975). Adaptations to extreme environments. In: Verberg, F. J. (ed.) Physiological ecology of estuarine organisms. University of South Carolina Press, Columbia, p. 165-180

Wheeler, D. E. (1978). Semilunar hatching periodicity in the mud fiddler crab Uca pugnax (Smith). Estuaries 1. 268-269

Manuscript first received: April 10, 1989

Revised version accepted: June 21, 1989 